University of the Pacific

Scholarly Commons

College of the Pacific Faculty Articles

All Faculty Scholarship

$12-1-2001$

\title{
Flooded: The Excesses of Geography, Gender, and Capitalism in Faulkner's If I Forget Thee, Jerusalem
}

Cynthia Dobbs

University of the Pacific, cdobbs@pacific.edu

Follow this and additional works at: https://scholarlycommons.pacific.edu/cop-facarticles

Part of the English Language and Literature Commons, Feminist, Gender, and Sexuality Studies Commons, and the History Commons

\section{Recommended Citation}

Dobbs, C. (2001). Flooded: The Excesses of Geography, Gender, and Capitalism in Faulkner's If I Forget Thee, Jerusalem. American Literature, 73(4), 811-835. DOI: 10.1215/00029831-73-4-811

https://scholarlycommons.pacific.edu/cop-facarticles/278 
Cynthia Dobbs

Flooded: The Excesses of Geography,

Gender, and Capitalism in Faulkner's If I Forget

Thee, Jerusalem

Overshadowed by his four masterpieces of the late 1920's and 1930's (The Sound and

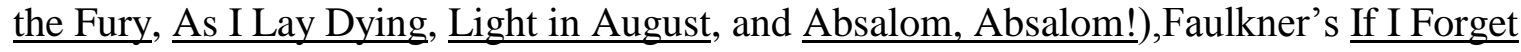
Thee, Jerusalem [first published as The Wild Palms in 1939] ${ }^{\mathrm{i}}$ has never garnered the sustained critical attention bestowed upon these Depression-era heavyweights. However, the novel has recently begun to draw scholars to it, as if we'd caught up with Faulkner at last ${ }^{\text {ii }}$. I will argue that this odd double narrative of If I Forget Thee, Jerusalem deserves a closer look, for in it Faulkner crystallizes the central themes of his earlier major works and raises the stakes of his representations of an anguished South. As in his earlier novels, Faulkner explores central modernist preoccupations: the slippery relationships among memory, history, and myth; the agonizing yet aesthetically energizing task of constructing a narrative of history and self in a world where objectivity is clearly impossible and the grounds of subjectivity are always in question; and the problem, given cultural and psychological anxieties about race, gender, and sexuality, of articulating an embodied identity. Alongside other modernist writers, Faulkner was grappling with these specific philosophical, psychological, sociopolitical, and aesthetic issues, as well as with a growing sense of the underlying radical flux of experience itself. Throughout Faulkner's work, this terrifying yet fascinating flux is represented in gendered

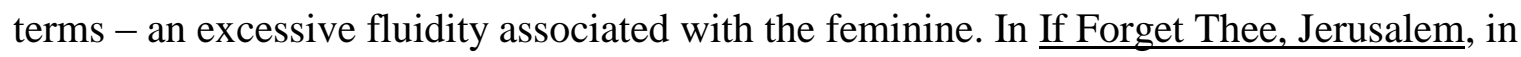
particular, Faulkner explores his culture's fear of radical fluidity in terms that connect women's bodies (as powerful sites of origin, seduction, and contamination) to both a radically feminized landscape and a dangerously volatile free-market economy. I will argue that every aspect of early-twentieth-century American culture some might wish to consider stable - 
gender, geography, the logic of capitalism - proves, in If I Forget Thee, Jerusalem, to be a source of profound chaos.

I do not mean to suggest a simple or "natural" equation of female and fluidity, however. Although critical theorists from Plato to Irigiray have characterized solidity as masculine and fluidity as feminine, I am interested less in how Faulkner's representation of an unmoored landscape echoes this perceived gender division than in how his novel raises questions about the grounding of this conception of gender in the natural. Thus, my aim here echoes Judith Butler's description of the mission of her book Gender Trouble: Feminism and the Subversion of Identity: "Indeed, the purpose here more generally is to trace the ways in which gender fables establish and circulate the misnomer of natural facts." ${ }^{\text {iii }}$ In If Forget Thee, Jerusalem Faulkner too calls into question the very idea of "the natural" as a viable category in this novel, revealing the ways in which fears of a seemingly natural feminine fluidity bleed into cultural anxieties about the unforgiving vicissitudes of a constitutively fluid free-market capitalism, an economy whose essential unpredictability would become most evident in the 1920s and 1930s ${ }^{\mathrm{iv}}$.

Fluid Aesthetics

Readers of If I Forget Thee, Jerusalem first encounter fluidity in the odd terrain of the novel's structure. As its critical history and contested title attest, If I Forget Thee, Jerusalem is a divided work, whose split structure has generally been considered a failure. Irving Howe has explained that most critics consider the alternation of "The Wild Palms" and "Old Man" sections unnecessary and undeniably an artistic failure. Howe notes that Malcolm Cowley, for example, felt free to publish "Old Man" separately in The Portable Faulkner, reasoning that its extraction from "The Wild Palms" came at no price. Howe himself remains a bit more measured in his own critique: "Probably of little use to anyone but himself, Faulkner's device of alternating sections of the two stories may be judged a tour de force that partly succeeds."v 
The more than partial success of Faulkner's strategy stems, it seems to me, from the ways in which the two narratives, like jazz riffs, play off each other's themes. Although Faulkner claimed that he added the "Old Man" narrative after having started "The Wild Palms" "simply to underline the story of Charlotte and Harry," the manner in which the tall convict's tale in "Old Man" "underline[s]" "The Wild Palms" is far from simple or obvious. vi "The Wild Palms," set primarily in 1938, centers on the doomed [I cut "love"] affair of Charlotte and Harry, two lovers caught between idealized notions of romantic love and the grim, pervasive socioeconomic realities of the late 1930s. "Old Man," set in 1927, tells of the nameless "tall convict," who, initially imprisoned (literally and figuratively) by the idealized notions of masculinity he has adopted from pulp fiction, finds himself caught in a flood that is both physical and metaphysical. The convict's ideas of self and world are consequently overwhelmed not only by a landscape that has turned unreadable but also by his forced proximity to a pregnant woman whose body he finds monstrous and threatening. While in "Old Man," pregnancy is a site of unsettling anxiety for the tall convict, in "The Wild Palms" sections, pregnancy ultimately dooms the protagonists Harry and Charlotte. [syntax changes] Charlotte's experimentation as an artist and as a woman pushing against the social constraints of gender are ultimately annihilated by the economic and cultural realities of the 1938 world of the novel; financial scarcity and the illegality and perceived immorality of abortion doom Charlotte to death and Harry to prison at Parchman, the same prison the tall convict calls "home" in "Old Man."

However tangential the links may initially seem between these two narratives, their sites of connection and contrast are integral to each narrative's power and to the aesthetic power of the novel as a whole. While Howe argues that the "Old Man" sections act as a sort of comic relief to the unremitting tragedy of Charlotte and Harry's story, I would like to emphasize the ways in which a certain reading of "Old Man" and "The Wild Palms" can in fact deepen and enrich our understanding of the tragic nature of both narratives. ${ }^{\text {vii }}$ For in the tale of the tall convict's circular journey, whose origin and goal are a return to a purely masculine and asexual world, lie the seeds 
of Harry and Charlotte's tragedy. In fact, the male protagonists in both narratives find themselves frozen by their fears of female fertility and creativity, emblematized by pregnancy. Ultimately, even more paralyzing than this terror are the characters' associations of pregnant women with the dubious seductions of a volatile, emphatically fluid capitalist economy. This link between patrimonial obligation and financial responsibility amidst a terrifyingly unstable economy would not, of course, seem remote to Faulkner himself, who wrote If I Forget Thee, Jerusalem in his Hollywood years, when he was desperate to keep his family financially afloat.

Flood as Fact, Flood as Metaphor

As John Barry explains so compellingly in Rising Tide: The Great Mississippi Flood of 1927 and How It Changed America, the flood that Faulkner represents in the "Old Man" sections of If I Forget Thee, Jerusalem was an extraordinary historical event. ${ }^{\text {vii }}$ Waters thirty feet deep stretched from Illinois to Louisiana, killing thousands and leaving roughly a million people homeless. ${ }^{\text {ix }}$ That Faulkner chose a setting of historical import to the South for "Old Man" is not surprising, but the Mississippi flood of 1927 was particularly evocative for Faulkner, and not simply because of the flood's unprecedented physical impact on the Southern landscape. While it was a natural event of nearly mythic proportions, the flood was also a sociopolitical event, resulting as much from corrupt public policy as from the whimsy of nature. According to Barry, the Great Flood of 1927 was greatly exacerbated by power struggles among key political figures attempting to control the Mississippi -- a struggle that led to an ultimately treacherous "levees-only" policy and to subsequent decisions to flood rural areas in order to ease the threat to New Orleans, where many of the political and social elite in Louisiana lived. ${ }^{\mathrm{x}}$ In "Old Man," Faulkner depicts this manipulation of the landscape itself for the vested interests of the privileged classes (226-229). Here, the Cajun man's property (not to mention his safety) is simply not an issue for the government workers assigned to dynamite the levee protecting it. The workers' orders are to 
destroy the farms and swampland occupied primarily by impoverished whites and "mixed bloods" in order to save the property of the wealthy citizens of New Orleans. ${ }^{\mathrm{xi}}$

While the "Old Man" thus concerns itself with a historical event that blurred the boundaries between social control and the forces of Nature [I cut the scare quotes], the very nature -- the physical character -- of the Mississippi River also served as a rich source of metaphor for Faulkner. Notoriously unpredictable and idiosyncratic in its flows, the Mississippi becomes an apt metaphor in the novel for a certain conception of Woman, for the dangerous unpredictability of capitalism (revealed so profoundly in the 1930s), and for the structure of the novel itself, whose dual narratives can be read in terms of flows and counter-flows. As both Barry and Faulkner, among others, describe it, the Mississippi in flood is more akin to an amalgam of rivers, flowing at cross-currents. Like the currents of the flooded river, the narratives of If I Forget Thee, Jerusalem flow counter to one another. The story of Charlotte and Harry, which begins the novel, is told largely in reverse chronological order; we see these characters first as Charlotte is dying in New Orleans, and the narrative flows backwards in time from there, until the final section, which picks up from the beginning chapter and moves us through Charlotte's death and its aftermath. Conversely, the "Old Man" section moves along in a more or less straight chronological line. So, while "The Wild Palms" starts us off in medias res, "Old Man" begins, like a mythic fairy tale, from the very beginning: "Once (It was Mississippi, in May, in the flood year 1927) there were two convicts" (20).

This beginning of "Old Man" immediately introduces another flow and counter-flow, as the story's opening line pits the forces of history against the power of myth. The syntax of "Once (It was Mississippi, in May, in the flood year 1927) there were two convicts" demonstrates, in miniature, the ways in which historical particularity insists its way into the attempted seamlessness of myth; Faulkner's delineation of location, season, and year disrupts the mythic, fairy-tale rhetoric of "Once [upon a time] [...] there were two convicts." Faulkner appears to want to tell (at least) two discrete yet inextricable stories at once -- one mythic, one more 
historically circumscribed. Indeed, in their very namelessness, and in their struggles against the primal forces of the flood, the tall convict and the unnamed pregnant woman of "Old Man" take on mythic dimensions. They become increasingly unmoored from all historically and geographically recognizable locations, as they lose sense of what state they are in and even of the number of days or weeks passing. Moreover, the convict's goal seems emphatically ahistorical: to return to the static community of men in prison in order to be free, as he puts it, of "all pregnant and female life forever and return to that monastic existence of shotguns and shackles where he would be secure from it"(130). Through the tall convict, Faulkner thus links the flow of the floods, the flow of history, and the fluid possibilities for sexuality, reproduction, and growth emblematized by the pregnant woman; in addition, he explicitly pits these fluid forces against a predictable, monastic, masculine world that is simultaneously prison and home.

In "The Wild Palms" sections of the novel, Faulkner renders the tension between the mythic and the historical in even more overt terms. The drama of Charlotte and Harry's narrative springs from their desire to escape the social confines of their lives in the late Depression era and to enter a transcendent realm of romantic love. Although they attempt to create a mythic love that rises above the social laws of marital fidelity and propriety, their love remains contaminated, as Harry sees it, by their economic struggles during the Depression. I will later elaborate on the ways in which the mythic purity of their love is disrupted by the economic forces of the 1930s and by historically circumscribed notions of what is natural about female bodies. The point I wish to emphasize is that Faulkner's preoccupation with the tension between the mythic and the historical resonates throughout Jerusalem, from the sentence level ("Once [It was Mississippi, in May..."), to the organization of the two interwoven narratives, to Faulkner's figure for that structure- the oppositional layers of the Mississippi River:

It was as if the water itself were in three strata, separate and distinct, the bland and unhurried surface bearing a frothy scum and a miniature flotsam of twigs and 
screening as though by vicious calculation the rush and fury of the flood itself, and beneath this in turn the original stream, trickle, murmuring along in the opposite direction, following undisturbed and unaware its appointed course and serving its Lilliputian end,

like a thread of ants beneath the rails on which an express train passes, they (the ants) as unaware of the power and fury as if it were a cyclone crossing Saturn. $(53-54)$

In addition to painting the Mississippi as a river literally at cross-purposes, Faulkner introduces a figure of assaulted masculinity. The "original stream" describes, at least implicitly, the "original" Mississippi River, or the "Old Man" of the section's title -- an emblem in this novel of the archetypal original father, the sire whose fraught primogeniture is a common obsession in Faulkner's work. ${ }^{\text {xii }}$ This original stream runs counter to and is rendered a relative "trickle" by the "rush and fury of the flood itself," which Faulkner associates with a terrifying archetypal female fluidity and with an overwhelming modernity, figured here in the "express train."xiii

Faulkner also portrays masculine authority as threatened by an overpowering femininity and a terrifyingly unstable modern economy through his ongoing thematic exploration of radical shifts in perception and perspective -- shifts prompted, in the "Old Man" sections, by the flooded Mississippi itself:

Then the taller convict became conscious of another sound. He did not begin to hear it all at once, he suddenly became aware that he had been hearing it all the time, a sound so much beyond all his experience and his powers of assimilation that up to this point he had been as oblivious of it as an ant or a flea might be of the sound of the avalanche on which it rides.(61) 
Here and throughout the "Old Man" sections of the novel, Faulkner depicts the flood as a terrifying otherness so overpowering as to realign the convict's perception of the world and his place within it. At the same time, this otherness is revealed as a kind of fluid, amorphous foundation to all experience -- something simultaneously "beyond all [...] experience" and always already there (“... he suddenly became aware that he had been hearing it all the time"). By revealing the enormously unsettling volatility of the literal and metaphysical ground of being itself, the flood breaks open the convict's perceptual world. He becomes immersed in "a state in which he was toy and pawn on a vicious and inflammable geography" (137). Throughout the novel, this "inflammable geography" is deeply associated with both female sexuality and capitalism.

Faulkner thus presents us with a dual ontological shift in the convict's perspective. He regards himself not as a hero in a dime store novel but as "an ant or a flea," "a toy and pawn," or, as he thinks later, "no more than a water bug upon the surface of a pond, the plumbless and lurking depths of which he would never know" (222); and of his world not as solid ground, but as "avalanche" or "cyclone" or furious flood. Through these striking metaphors, Faulkner makes external, physical, and literal a sense of disorientation that he renders in his earlier novels in primarily intrapsychic and social terms. The sense of radical disintegration and of selfannihilating insignificance that, for example, Quentin in The Sound and the Fury and Vardaman in As I Lay Dying express is generally contained within those characters' psychic and linguistic economies. ${ }^{\text {xiv }}$ Similarly, Faulkner moves between the psychological and sociohistorical realms in Light in August and Absalom, Absalom!, figuring his characters' distress as informed by an American sociopolitical history of slavery and the Civil War. In Jerusalem, however, Faulkner makes central a figure from natural history -- the Mississippi Flood of 1927 -- to expand this sense of radical disorientation to include the very landscape on which his characters attempt to ground themselves. ${ }^{\mathrm{xv}}$ 
Unlike Quentin, Vardaman, or even Darl, the convict initially responds to this elemental dis- and reorientation not with anguish or madness, but a quiet equanimity:

Instead and for the first time he looked at the River within whose shadow he had spent the last seven years of his life but had never seen before; he stood in quiet and amazed surmise and looked at the rigid steel-colored surface not broken into waves but merely slightly undulant. It stretched from the levee on which he stood, further than he could see -- a slowly and heavily roiling chocolate-frothy expanse broken only by a thin line a mile away as fragile in appearance as a single hair, which after a moment he recognized. It's another levee, he thought quietly. That's what we look like from there. That's what I am standing on looks like from there. (62)

Here the floods prompt the convict to see himself, for the first time, as the object of someone else's gaze. While this shift in perspective might mark a maturation from his previous boyish, narcissistic sense of himself as a dime-store hero, the convict's "quiet and amazed surmise" soon becomes anxiety. The ground that supports him suddenly seems "as fragile in appearance as a single hair." The fluidity emblematized by the river under whose shadow he has unconsciously lived does not initially bring forth fear, but instead a certain healthy humility. However, as I will show in the next section, once this fluidity is associated with anxieties about the female body and, by extension, capitalism, it becomes for both the hero of the "Old Man" and Harry of "The Wild Palms" a source of great fear and hatred. [trying to avoid "anxiety" twice in one sentence]

Flooded: Of Wombs, Water, Mules, and Money 
In "Old Man," Faulkner repeatedly connects the dangers of the Mississippi flood of 1927 with the body of the young pregnant woman whom the convict reluctantly takes on as his burden. Land, or solidity, becomes equivalent to the convict's release from, as he puts it so delicately, the "female meat" that threatens him. [I'd like to keep "so delicately," if you don't mind.] The novel is rife with descriptions of the convict's increasing terror of both the pregnant woman and the flood, but the following quotations should suffice as examples:

He watched her, he made no further effort to help her beyond holding the skiff savagely steady while she lowered herself from the limb -- the entire body, the deformed swell of belly bulging in calico, suspended by its arms, thinking, $\underline{\text { And }}$ this is what I get. This, out of all the female meat that walks, is what I have to be caught in a runaway boat with. (126)

He just wanted to get rid of the woman, the belly, and he was trying to do that in the right way, not for himself, but for her. He could have put her back into another tree any time. (136)

$[\mathrm{H}]$ is only other crying urgency was to refrain from looking at the woman who, as vision, the incontrovertible and apparently inescapable presence of his passenger, returned with dawn, had ceased to be a human being and [...] had become instead one single inert monstrous sentient womb from which, he now believed, if he could only turn his gaze away and keep it away, would disappear. (137)

As "vision," the pregnant woman is reduced to her reproductive organs, which are figured as "monstrous" and "inert." Yet, what is remarkable about this final passage in particular, aside from the explicitness of its misogyny, is Faulkner's emphasis on the woman precisely "as vision" -- a 
creation, that is, of the convict's "gaze." [I cut "sheer".] Critics who ponder the sexual politics of the novel, simultaneously incorporating as it does such grotesque visions of the nameless pregnant woman in "Old Man" and a forceful heroine in Charlotte in "The Wild Palms," often cite the novel's antagonism toward women as its fundamental flaw. David Minter, for example, counters Howe's assessment of the novel's structural failings by claiming that "the larger problems of the book have little to do with its form but much to do with its women," and "though the novel treats Charlotte's toughness and gallantry with genuine admiration, it also manifests deep suspicion and rancor toward women." ${ }^{\text {vvi }}$ While I essentially agree with Minter here, I also think it's important to note that even in these most explicit declarations of misogyny lies something more complicated, in that Faulkner emphasizes this grotesque view as a clear projection of the convict's own warped vision.

Just as we are meant to grasp the embarrassing gullibility behind the convict's wholesale belief in pulp fiction's portrayal of crimes that he attempts to copy, we are, I think, meant to look askance at the convict's perspective on women. It is worth remembering that the convict is in prison in the first place because of his naive belief that if he follows the "rules" of the "paper novels" he reads, he will become a heroic train robber. And, in a move of crafty naivete, the convict considers the authors of the mythic Westerns he reads responsible for his own inability to distinguish mythic fiction from a more complex and frequently humiliating reality. While in prison the convict directs his "outrage" not at the men who caught him or at his own former gullibility, but at pulp fiction's "ignorant" verisimilitude:

[His] an outrage [was] directed [...] at the writers, the uncorporeal names attached to the stories, the paper novels -- the Diamond Dicks and Jesse Jameses and such-whom he believed had led him into his present predicament through their own ignorance and gullibility regarding the medium in which they dealt and took 
money for, in accepting information on which they placed the stamp of verisimilitude and authenticity. (20)

Despite the cost of his own former gullibility (one which he projects onto authors), the convict remains an uncritical consumer of pulp fiction ${ }^{\text {xvii }}$. In prison, he allows the "impossible pulpprinted fables carefully censored and as carefully smuggled into the penitentiary" to form his ideas of women and his relationship to them: "[A]nd who to say what Helen, what living Garbo, he had not dreamed of rescuing from what craggy pinnacle or dragoned keep when he and his companion embarked in the skiff" (126). Imagining an ideal and mythic "Helen" or "Garbo" (figures who connote their own dangers), the convict is ill-prepared to encounter a "real" fleshand-blood woman, least of all a pregnant one.

As Faulkner stresses, the tall convict's vision of the pregnant woman as monstrous womb is formed not only by these same magazine's two-dimensional portrayals of women but also by the convict's ten years in prison: "anything he might reach and surrender his charge to and turn his back on her forever, on all pregnant and female life forever and return to that monastic existence of shotguns and shackles where he would be secure from it" (130). Clearly, there is some authorial distance and irony in this description of prison as a "monastic" realm of freedom and security ("monastic," yet defined by "shotguns and shackles"). Faulkner thus divorces himself from the convict's odd romanticism -- a romanticism that leaves him terrified of and disgusted by the reality of women "in the flesh," particularly one so fleshly in her pregnant state. Rather than simply seeing this "deep suspicion and rancor toward women" as the source of "the larger problems in the book," we [I cut "thus"] might instead ask how Jerusalem imagines the larger social and psychological problem of misogyny, particularly cultural fears about maternity and female sexuality.

Deborah Clarke's important work in Robbing the Mother: Women in Faulkner follows just such a line of inquiry. She argues [I cut "rather persuasively"] that the "collision between 
fluidity and solidity throughout the novel can be read as a struggle with maternal power."xviii Citing Barbara Johnson's definition of the "maternal function" as "the drama of simultaneity of attachment and detachment," Clarke contends that the central tension between the two parts in the novel and among the characters is ultimately about this maternal function, about the "struggle between fear and envy of a maternal function which represents home and not-home, the uncanny source of life and death."xix If the novel is indeed about this dialectic between "fear and envy of a maternal function," I would argue that fear clearly outweighs any envy in Faulkner's novel. Indeed, Clarke's claim that the pregnant woman is "the only major character left alive and free at the end of the book" and that "the lack of closure to her story grants her a pervasive quality none of the other characters enjoy" seems to me a bit wishful. For in many ways we never know the pregnant woman as a character. Instead, we always encounter her as the convict's "vision" of monstrous fluidity. ${ }^{\mathrm{xx}}$ In fact, through the lens of the convict's fear, the pregnant woman's corporeality grows so enlarged -- and her interiority so opaque -- that she becomes, in a sense, loosed from her very flesh and her very particularity as a character. She and the river become one: a malevolent nature whose "creative fluidity" is actually all about destruction.

To escape from this woman-womb-flood and to return to his "home," Parchman Prison, become the convict's goals. Prison as a figure for Jerusalem, and exile as freedom, may initially seem odd. But given the seeming alternative in "Old Man -- of engulfment within the treacherous floods of desire and society -- the convict's nostalgia for Parchman makes a certain sense. Indeed, the convict's depiction of prison as a place of purified desire and satisfaction makes him seem, within the all-male "monastic existence of shotguns and shackles," like a Freudian picture of health: in prison, he remains content in work and love. The unchanging safety of Parchman, and of the temporary island he finds with the Cajun man, clearly has to do [syntax changes] with the solidity associated with a freedom from women and the simultaneous disgust and sexual desire they elicit. In the narrative of the convict's stay with the Cajun, his pregnant companion's presence fades dramatically from the text, and a "happy marriage" of 
wordless work emerges between the Cajun and the convict, just as in prison, the convict's happy marriage is with his mule, John Henry.

While one might thus argue for a sort of homoerotic subtext in "Old Man," the desire this section depicts seems to me all about the longing to transcend, or entirely avoid, sexual desire itself. Both of these examples of the convict's attachments remain perfectly free from sexual desire, and notably, from language and the social contracts desire and discourse necessarily entail. ${ }^{x x i}$ Indeed, the mule becomes an especially evocative image for the convict's "Jerusalem" of perfect work and love precisely because of its asexual nature, its inability to reproduce. David Minter examines the lure of the mule to Faulkner, both in this work and in his life:

During the summer, with The Wild Palms finished, he spent much of his time stocking his farm. Years before, in the first of his Yoknapatawpha novels, he had celebrated the mule's imperviousness to time and circumstance; its loyalty 'to the land when all else faltered'; and finally its insistent singularity. It possessed, he recalled, a built-in principle of retirement, and so resisted the most entangling of alliances: 'Father and mother he does not resemble, sons and daughters he will never have.' Now, despite the protests of his brother John, who had agreed to run Greenfield Farm for him, Faulkner insisted that they raise mules rather than cattle. $^{\text {xxii }}$

As a figure constitutively divorced from sexuality and, in human terms, sexuality's attendant psychological, social, and financial entanglements, the mule becomes a perfect love interest for the convict and a perfect model of detachment for Faulkner. Always already separate from reproduction, the mule serves as a figure for a crucial purity and "freedom" within the world of this novel, a world in which reproduction (central both to women's "maternal function" and to capitalism) is equivalent to a site of frightening contamination. 
In addition to the obvious homosocial and asexual nature of the convict's relationships with the mule and the Cajun man, both partnerships are strikingly characterized by a paradoxical dual engagement with work and disengagement from a cash economy. In prison, the convict and John Henry work daily in the fields, taking pleasure in the work itself and in the connection to "the land when all else faltered."xxiii Because the convict's needs for food, clothing, and shelter are met in the womb-like security of this prison [note change in syntax], the work he does is (for him, at least) utterly separate from any visible system of exchange. Thus, work becomes a sort of reliable, abstract, pure pleasure divorced from the insecure marketplace. [Note excision of final clause.]

Similarly, when the Cajun enlists the convict's help in killing and skinning alligators -- a sort of Ur-Masculine work for which the convict has a soon-legendary affinity -- the contamination of a cash economy is always kept at a distance. Even though, as the convict claims in his narration of his time with the Cajun, "Yes. I reckon I had done forgot how good making money was. Being let to make it" (219), Faulkner makes a point of divorcing "money" from its usual links to a capitalist system. The convict may claim that he has no need for language with the Cajun man, because "money aint got but one language" (217), but the word "money" in this section is actually detached from its conventional referent to a unit of exchange in a cash economy. In fact, when the issue of money is first raised [avoids repetition of "introduces"] as a factor in the alligator hunting, to which the Cajun introduces the convict, the convict is utterly surprised. After seeing the convict kill an alligator with his own hands, the Cajun says, “Magnifique! Magnifique! Cent d'argent! mille d'argent! Tout l'argent sous le Ciel de Dieu!" to which the convict thinks, "It's a little late to be telling me that now" (217). Notably, the introduction of money comes, for the convict, in the form of a "foreign" language; also, even in creole, the exact amount escalates to mythic proportions: from hundreds to thousands to "all the money under God's sky." Thus, while the two men's alligator hunting remains part of an economic exchange, the accounting here is so emphatically grandiose and abstract as to remain 
separate from the wider economic system. The convict soon learns, in fact, that "it was a question of money in terms of time, days," and ultimately, in terms of alligator skins (261). The Cajun's home thus becomes a sort of preindustrial, masculine island amidst the floods of late-1920s capitalism run amok -- a space, like Parchman Prison, free of the contamination associated with women and a cash economy.

In "The Wild Palms" section that begins the novel, Faulkner introduces this theme of female and socioeconomic contamination through the eyes of the nameless Doctor, who serves as an ironic counterpart to the nameless convict of the "Old Man" section. Though married and in a profession that by definition entails an engagement with the body, the Doctor in the opening chapter of Jerusalem is, like the tall convict and in apparent opposition to the passionate Charlotte and Harry, defined both by his gullible, pervasive acceptance of dubious "gender fables" and by his (related) celibacy. For example, the Doctor establishes his masculinity by donning a night shirt and eschewing cigarettes because he is told "at sixteen and eighteen and twenty... that cigarettes and pajamas were for dudes and women"(4). Although he chooses the opposite sides of the coin of mythic masculinity (the convict wants to seem "a dude"; the Doctor doesn't), the Doctor is nonetheless playing with the same feeble coin. Moreover, the rigidity of the Doctor's notions of gender seem clearly related to the sterility of his marriage, which remains about as (re)productive as the relationship between the convict and his mule John Henry, though perhaps less affectionate.

Significantly, the novel begins with the Doctor's paradoxical perspective on gender. Like the tall convict, he is horrified by the sight of a woman's body. Charlotte Rittenmeyer's body becomes a site of "outrage" not because she is visibly pregnant by Harry (who the Doctor realizes is not her husband, their adultery as apparent somehow as if they were Hawthorne's characters) but because she obviously was pregnant by Harry. The horror of the chapter unfolds as the asexual Doctor realizes the "inviolable truth" of Charlotte's condition: that she is slowly dying from the effects of a botched abortion. 
Thus, while the horror of femaleness in "Old Man" lies in its "outrage[ous]" visibility, emblematized by the flood and the pregnant woman's belly, the terrifying feminine flux in "The Wild Palms" is at first invisible, though emphatically present in two forms: wind and blood. What water is to the "Old Man" sections, wind and blood are to "The Wild Palms" sections. Wind, the invisible force behind the "wildness" of the "wild palms," and blood, whose invisible seeping within Charlotte suggests both a terrible secret and a tragic fate, become figures for a covert feminine threat to stability, permanence, and safety. Like a stealthy flood (and, as I will argue, like time and experience itself), wind and blood mark an uncontainable flux associated with female sexuality and capitalism. From the beginning of the novel, the invisible presence of both wind and blood pervade. For example, when the Doctor wants to know the time, he doesn't look at a clock; instead, he knows what time it is from "the taste and smell and feel of wind even here behind the closed and locked doors and shutters" (4). Similarly, he cannot see Charlotte's injury, but he can sense a wound that is, as it were, behind the veil of her very flesh.

Through the Doctor's gaze, we receive a rare physical description of Charlotte, an exterior description that quickly turns its focus to the invisible interiority of the body:

the dark-haired woman with queer hard yellow eyes in a face whose skin was drawn thin over prominent cheekbones and a heavy jaw (the doctor called it sullen at first, then he called it afraid), young, who sat all day long in a new cheap beach chair facing the water, in a worn sweater and a pair of faded jean pants and canvas shoes, not reading, not doing anything, just sitting there in that complete immobility which the doctor (or the doctor in the Doctor) did not need the corroboration of the drawn quality of the skin and the blank inverted fixity of the apparently unseeing eyes to recognize at once -- that complete immobile 
abstraction from which even pain and terror are absent, in which a living creature seems to listen to and even watch some one of its own flagging organs, the heart say, the secret irreparable seeping of blood . (5)

While the Doctor may first imagine, rather prosaically, that Charlotte's "flagging organ" is her heart, we soon learn that it is, in fact, her womb that suffers from a fatal "secret irreparable seeping of blood." The Doctor's outrage at this knowledge is directed at its "proof" not only of a sexual love that exceeds the boundaries of 1930s social propriety, but also of an attempt, through abortion, to thwart what is conventionally considered the natural law of female biology. The Doctor echoes, then, in ironic counterpoint, the tall convict's outrage at the very fact of female biology and sexuality in the form of the pregnant woman's body. Although the Doctor is horrified by an aborted pregnancy while the convict is terrified by a "successful" pregnancy, each expresses a fear of female agency and power. Furthermore, female sexuality connotes, in those years before Roe v. Wade, the "threat" of pregnancy. In turn, the prospect of children entails a certain commitment to engagement with the socioeconomic order (or disorder) of the Great Depression. Pregnancy thus implies an entire set of parental roles and economic responsibilities that most of the characters in this novel fear desperately. Reproduction and responsibility for a child thus becomes tantamount to contamination by socioeconomic forces of production and reproduction -- forces that, in the 1920s and 1930s, were particularly fraught with danger. Just as the pregnant woman in "Old Man" remains unfazed by the "threat" of her pregnancy and by the principles of excess she seems to represent, Charlotte seems initially undaunted by the perils of either the market or her own sexuality. Yet, Faulkner reveals that Charlotte's relationships to both money and sexuality are tremendously conflicted; in fact, Charlotte's character is shot through with contradiction. First, Charlotte is much more than her body, more than a sort of floating womb. Her desires seem, in fact, the opposite of the pregnant 
woman's in "Old Man," a contrast revealed most explicitly in the fact that Charlotte wants an abortion while the pregnant woman's mission in "Old Man" is to deliver her baby safely. If the pregnant woman in "Old Man," like Lena Grove in Light in August, emblematizes in a conventional (and disturbing) manner simplicity and fecund femininity, Charlotte Rittenmeyer resists such conventional representations. She dresses "like a man," in her "faded jean pants and canvas shoes"; she rejects her "maternal function," first by leaving her husband and children for Harry and for a life as an artist and then by choosing to have an abortion; she is the sexual aggressor in her relationship with Harry; and, at several points, she is the main breadwinner for the couple. Indeed, as Harry puts it: "She is not only a better man and a better gentleman than I am, she is a better everything than I will ever be" (174).

Janet Carey Eldred has argued that Faulkner uses Charlotte's unconventional character to pursue two definitions of artistic creation in Jerusalem: aesthetic creation as procreation (symbolized by the pregnant woman in "Old Man") and creation as "still life," emblematized in Charlotte's own artwork and aesthetic philosophy and in her related decision to "still life" by having an abortion:

If Hawthorne criticizes sculpture's inability to evoke narrative, Faulkner praises it because it communicates motion through stillness ....[Use four ellipses.] Faulkner regularly stated that the aim of the 'artist is to arrest motion, which is life, by artificial means' (LG253). [LG253 is Eldred's citation of "artist is to arrest motion..." which comes from Lion in the Garden, a biography of Faulkner. How do you cite internal citations??] Indeed, both as an artist and a woman, Charlotte will still life through 'artificial' means.[...] To preserve her affair with Harry, to 
keep their love 'solid and fine,' she will try again to still time and thwart change. ${ }^{x i v}$

While Eldred connects Charlotte's choice of abortion to Faulkner's declared aesthetic principles, she argues, in effect, that by killing Charlotte off [syntax changes], Faulkner backs away from the political implications of this connection:

In The Wild Palms, a powerful middle-class Christian discourse which focuses on 'natural' sexuality and (pro)creativity opposes Charlotte and Harry as lovers, as renegades from the middle class[...]. As the ending reveals, Faulkner in The Wild Palms succumbs to the powerful rhetoric of "family," to a powerful procreative metaphor for artistic production. ${ }^{\mathrm{xxv}}$

Indeed, Charlotte's artistic goal is to create objects that are more permanent than life, emphatically tougher than the body itself. As she puts it, “That's what I make: something you can touch, pick up, something with weight in your hand that you can look at the behind side of, that displaces air and displaces water and when you drop it, it's your foot that breaks and not the shape...." (35). Yet, if to "still life" is an aesthetic goal attributable to Charlotte in Faulkner's novel, this goal is also gendered [I cut "I suggest"] as a particularly masculine aim. For Charlotte's longing to "still life," to arrest the flow of time, is enacted through her very rebellions against conventional notions of femininity.

In rather vertiginous fashion, just as Faulkner allows Charlotte these gender transgressions (only, in the end, to have them destroy her), so he depicts Harry as crossing over 
his own gender lines. While Charlotte works on creating immutable objects, Harry takes up the job as writer for popular confession magazines. In contrast to (and sometimes like) the supposed verisimilitude of the male-oriented pulp fiction the tall convict consumes, Harry writes his "confessions" as if he were a woman: "[Harry's] stories beginning 'I had the body and desires of a woman yet in knowledge and experience of the world I was but a child' or 'If I had only a mother's love to guard me on that fatal day"' (103), or, my favorite [yes, that's my voice - but you're free to cut it if you think it's too cutesy], "At sixteen I was an unwed mother" (104). As if this gender-bending weren't dizzyingly ironic enough, Faulkner goes on to describe Harry's writing process as akin to "the half-back working his way through school who grasps the ball [...] and runs until the play is completed" (103).

In one important sense, however, Charlotte's masculine hardness, her search for an antibourgeois purity, breaks down. Unlike Harry, Charlotte moves easily back and forth between a romantic desire for escape from the respectability of marriage and middle-class propriety and a pragmatic willingness to sacrifice her aesthetic and romantic ideals to make money. Granted, Harry does attempt to work (as a hack writer and as a doctor) but he remains always agonized by his entanglements with economic necessity. In contrast, Charlotte is less troubled and more fluid in her movement between a romantic ideal of living beyond and above social and economic concerns and an engagement with that same social world. She is less troubled, that is, until she becomes pregnant. For Charlotte, Faulkner implies, motherhood would be antithetical to free movement within and between an idyllic romantic, artistic life and a successful engagement with the economic world. Motherhood would lock her in a gender-determined prison; in short, biology becomes, for Charlotte, her destiny. In the end, as Eldred points out, Charlotte's life and body are "stilled" by her choice to end her pregnancy. Yet, as I've shown, continuing her pregnancy would 
also "still" Charlotte's successful movement in and out of the social world, as an artist, lover, and entrepreneur.

Bodies in Time: Flesh and the "Current That Runs Through

Remembering"

Faulkner's representation of Charlotte's "stilled" body returns us to cultural anxieties about the nature of gender, geography, and capitalism. In one remarkable passage, Charlotte claims an erotic association with water that contrasts starkly with the representations of water as horrifying Other in the "Old Man" sections:

\begin{abstract}
"I love water," she said. "That's where to die. Not in the hot air, above the hot ground, to wait hours for your blood to get cool enough to let you sleep and even weeks for your hair to stop growing. The water, the cool, to cool you quick so you can sleep, to wash out of your brain and out of your eyes and out of your blood all you ever saw and thought and felt and wanted and denied." (49-50)
\end{abstract}

Water's appeal to Charlotte is its erasure, its promise of a peaceful death of memory, loss, and longing; for Charlotte, water erases all traces of the body, of desire, and of time's passing. If in addition to serving as a figure for female sexuality and an unstable economy, the wildly disorienting flood stands as a figure for the flow of time, a flow that renders the characters helpless, bearing them along, bearing them away, then Charlotte surrenders happily to that flow and its endpoint in death, which, paradoxically, erases all time.

When Charlotte dies from the botched abortion, she gets her wish, in a sense, for Harry views her dead body as a body of water running beneath the earth: 
It was more than just a slackening of joints and muscles, it was a collapsing of the entire body as undammed water collapses, arrested for the moment for him to look at but still seeking that profound and primal level much lower than that of the walking and upright, lower than the prone one of the little death called sleep, lower even than the paper-thin spurning sole; the flat earth itself and even this not low enough, spreading, disappearing, slow at first then increasing and at last with incredible speed: gone, vanished, no trace left above the insatiable dust. (257)

Charlotte's body becomes water here, "undammed" like the flooded Mississippi in "Old Man." But this is water with a will to disappear, to seek some level beyond "that little death called sleep" (and sexual climax), to reach a spaceless space beyond history's ability to recall her. Whether in the form of the clear and cool water that soothes Charlotte as she swims, of the "undammed" water her dead body becomes, or of the roiling muddy flood that threatens the convict, the figure of water in Jerusalem finally functions as a medium of forgetting, of eradication of flesh and desire, of an erasure of history and all its traces.

This erasure or "transcendence" of the body and memory, Faulkner soon reveals, is a dubious desire. In choosing life, Harry seems to eschew the transcendence of time that Charlotte desired, instead returning to its flow of emphatically embodied memory. In a passage that raises the specter in Faulkner's work, once again, of a tragic war and losses encoded in the cryptic writing on tombstones, ${ }^{\text {xxvi }}$ Harry comes to realize that memory cannot be contained in the physical text of the epitaph, but must be held in the body:

[T]here would be a headstone soon, at just exactly the right time, when restored earth and decorum stipulated, telling nothing; it would be clipped and green and quiet, the body, the shape of it under the drawn sheet, flat and small and moving in the hands of the men as if without weight though it did, nevertheless bearing 
and quiet beneath the iron weight of earth. Only that cant be all of it, he thought. It cant be. The waste. Not of meat, there is always plenty of meat. They found that out twenty years ago preserving nations and justifying mottoes -- granted the nations the meat preserved are worth the preserving with the meat it took gone. But memory. Surely memory exists independent of the flesh. But this was wrong too. Because it wouldn't know what it was it remembered. So there's got to be the old meat, the old frail eradicable meat for memory to titillate. (265)

Echoing the convict's disdainful characterization of the pregnant woman as "female meat" and, in his grief, expressing a suicidal desire to transcend the body and time, Harry questions the connection between "the old frail eradicable meat" and memory. Unlike the convict, whose attitude toward "the flesh" remains one of nearly constant disgust, Harry here seems to depart from Charlotte's fantasy of transcending the body. He learns that in the end, memory remains dependent on "the body" of the one remembering -- not the one remembered -- and that he must, therefore, reenter the flow of time in order to keep Charlotte's memory alive. By remaining alive to mourn the loss of Charlotte, by returning, as he puts it in one remarkable passage, to the "current of time that runs through remembering," Harry appears to return to life and its culturally shaped exigencies, as well as to the painful task of remembering (116). The novel thus posits time as a flow that can erase memory, bodies, economic troubles, history itself - a flow of forgetting - as well as a flow that can "run through remembering."

Looking more closely at the split between Harry's rhetoric and his actions, however, we have to wonder what sort of "current" would flow through his memories of Charlotte. Harry's self-debate about the appeal of death vs. a life of "the current of time that runs through remembering" echoes Quentin and Mr. Compson's debate over grief and forgetting in The Sound and the Fury. Harry's choice to live, in order to keep the memory of Charlotte alive, separates 
him from Quentin (and Charlotte's) desire for the erasure that a watery suicide offers. He thus seems to choose a life-affirming entry into the "flow" of time. However, because life for Harry means, at the novel's end, a life within Parchman Prison (long established by the convict as a symbol of safe stasis, held apart from women and economics), the flow Harry chooses ultimately looks much more like a frozen tableau, a "still life." Harry's choice is really not so much to stop his own death and thereby enter the riskier business of living within a chaotic social world but to stop Charlotte's death, to stop her fading within time. Harry's memory thus functions to encrypt a vision of a living Charlotte. Ultimately, then, Harry chooses the stasis of melancholia over the true flow of mourning -- a flow which would leave him open to the emotional and economic risks of life's exigencies. ${ }^{\text {xxvii }}$

Directing the Flow: Convict as Author, Author as Convict

Like Harry at the conclusion of "The Wild Palms," the convict ends the novel within the pure time of his own construction, returning to his "Jerusalem," his home of mules and men at Parchman Prison. Safe in his unchanging prison, the convict also remains in control of the flux of time through authorial control over his own tale. That is, while the immutable all-male enclave of Parchman provides for a sort of timeless present and future, Faulkner also reveals the ways in which the act of narration itself can transform the flow of the past into the "still life" of story. When he tells the tale of his weeks on the flooded river, the convict chooses only certain scenes to paint for his fellow prisoners, primarily scenes of his idyllic days trapping alligators with the Cajun man. But Faulkner is emphatic in revealing the gap between the convict's story of his past and his memory of that past:

He told it -- of the next eight or nine or ten days, he did not remember which, while the four of them -- himself and the woman and the baby and the little wiry 
man with rotting teeth and soft wild bright eyes like a rat or a chipmunk, whose language neither of them could understand -- lived in a room and a half. He did not tell it that way, just as he apparently did not consider it worth the breath to tell how he had got the hundred-and-sixty pound skiff singlehanded up and across and down the sixty-foot levee. He just said, "After a while we come to a house and we stayed there eight or nine days then they blew up the levee with dynamite so we had to leave." That was all. But he remembered it, but quietly now.(211)

Intriguingly, in the convict's account to his fellow prisoners, he minimizes the sort of masculine heroics that would place him squarely in the role of dime-store novel hero he always desired. (At the same time, his laconic style makes him a fitting Western hero -- a man of action rather than words.) Most important, the convict omits scenes that relate his temporary immersion in and eventual escape from the outside world of floods, female sexuality, and the seductions and dangers of the marketplace. For example, he does not narrate certain key plot elements of his story: his work at a sawmill or his loss of that job after having an affair with the boss's wife. Standing on the solid ground provided by a pulp novelist's point of view, looking back on the past flow of time and ordering it through his telling, the convict finds yet another way to return to the safety of a timeless, all-male enclave.

However [I cut "I argue... that"], Faulkner's novel ultimately condemns this safety. After all, the convict's terse version of events remains so much less interesting than Faulkner's. In ordering the narrative of his journey so that the contradictions of desire are eliminated from the story, the convict has created only a dull tale of circularity. (One could reduce the convict's version to this: "I was forced from Parchman. I wanted to get back to Parchman, safe from female meat and the need for money. I had this skiff and this woman. I got rid of them. Now I'm back.") Safe from female sexuality and a frighteningly shifting geography and economy, the 
convict creates a "still life" that remains ultimately lifeless, a vastly diminished version of the Keatsian model of the Grecian urn that Faulkner held so dear.

\section{University of the Pacific}

I would like to thank Mitch Breitwieser, Anne-Marie Harvey, Daphne Lamothe, Courtney Lehmann, and Theresa Tensuan for their smart suggestions on earlier drafts of this article and for their ongoing support.

i While Faulkner's novel is more widely known as The Wild Palms, having been published under that name until 1995, Faulkner always preferred the title If I Forget Thee, Jerusalem, a reference to the exiled Israelites' song of lament in Psalm 137 of the King James Bible. All references to If I Forget Thee, Jerusalem will be to the Vintage Books edition (William Faulkner, If I Forget Thee, Jerusalem [The Wild Palms] (New York: Vintage Books, 1995]) and will appear parenthetically in the text. ii See especially Vincent Allan King, "The Wages of Pulp: The Use and Abuse of Fiction in William Faulkner's The Wild Palms, " The Mississippi Quarterly 51.3 (Summer 1998): 503-27; John T. Irwin, "Not the Having but the Wanting: Faulkner's Lost Loves," Faulkner at 100: Retrospect and Prospect, ed. Donald M. Kartiganer and Ann J. Abadie (Jackson: Univ. Press of Mississippi,2000): 154-64; and 
Thomas L. McHaney, "Oversexing the Natural World: Mosquitoes and If I Forget Thee, Jerusalem," Faulkner and the Natural World, ed. Donald M. Kartiganer and Ann J. Abadie (Jackson: Univ. Press of Mississippi, 1999): 19-44.

iii Judith Butler, Gender Trouble: Feminism and the Subversion

of Identity (New York: Routledge Press, 1990), xiii.

iv Joseph Schumpeter's classic definition of capitalism foregrounds this fluidity as a constitutive element: Capitalism, then, is by nature a form or method of economic exchange and not only never is but never can be stationary [...] The opening up of new markets, foreign or domestic, and the organizational development from the craft shop and factory to such concerns as U.S. Steel illustrate the same process of industrial mutation - if I may use that biological term - that incessantly revolutionizes the economic structure from within, incessantly destroying the old one, incessantly creating a new one. This process of Creative Destruction is the essential fact about capitalism. Capitalism, Socialism, and Democracy (New York: Harper and Brothers, 1947): 82-83. More contemporary theorists Gilles Deleuze and Felix Guattari stress this same sense of the radical fluidity 
of capitalism in their A Thousand Plateaus: Capitalism and Schizophrenia (Minneapolis: Univ. Press of Minnesota, 1987).

v Irving Howe, William Faulkner: A Critical Study (Chicago: Ivan R. Dee, Inc., 1991), 242. vi For the novel's fascinating composition history, see David Minter, William Faulkner: His Life and Work (Baltimore: Johns Hopkins Univ. Press, 1980), 170 - 177. Written in the midst of Faulkner's lucrative yet agonized years in Hollywood, the novel was, as Minter puts it, "written out of pain that was physical, marital and personal" (174-175). vii Howe states: "...for 'Wild Palms' by itself is almost intolerably painful and needs very much to be brought 'back to pitch'" (William Faulkner, 239).

viii John M. Barry, Rising Tide: The Great Mississippi Flood of 1927 and How It Changed America (New York: Simon and Schuster, 1997). Despite its rather melodramatic title, Barry's history is meticulously researched and skillfully written.

ix Ibid, 15-16.

x Ibid, 78-92.

xi Here, as elsewhere in Faulkner's fiction, the tension between rich and poor is both echoed and obfuscated by racial and gender conflicts. See Barry's description of the role of racism, particularly anti-black and anti-Italian racism, in 
the attempts to control the Mississippi River during the 1927 flood; Barry, 111-113 and 132-155. xii For a discussion of the anxieties of patrilineal and patriarchal genealogy in Faulkner's work, see especially John T. Irwin's classic Doubling and Incest/Repetition and Revenge (Baltimore: The Johns Hopkins Univ. Press, 1975); Carolyn Porter, "Absalom, Absalom! (Un)making the Father," The Cambridge Companion to William Faulkner (Cambridge Univ. Press, 1995): 168-196; and Philip Weinstein, What Else But Love? The Ordeal of Race in Faulkner and Morrison (New York: Columbia Univ. Press, 1996). xiii The way in which the representations of the flood are gendered is far from simple, however. For example, at one point the flood is said to have "regurgitated [the convict] onto the wild bosom of the Father of Waters" (158) -- an oddly double-sexed description that echoes Harry's gender-bending magazine personae. xiv Granted, the rains and flooded river in As I Lay Dying do echo the chaotic excess that many of its characters seek to contain. I argue, however, that the landscape in that novel serves to reinforce a dynamic already strongly laid about among the characters, while in Jerusalem the landscape actually has the agency and will of a character. xv The paradox, however, is that Faulkner walks the boundary 
between what is natural and what is social, and finds it decidedly permeable. xvi Minter, William Faulkner, 175-176.

xvii For further analysis of the function of pulp fiction in the novel, see Vincent Allan King's "The Wages of Pulp: The Use and Abuse of Fiction in William Faulkner's The Wild Palms," The Mississippi Quarterly 51.3 (Summer 1998): 503-27.

xviii Deborah Clarke, Robbing the Mother: Women in Faulkner (Jackson: Univ. of Mississippi Press, 1994), 117. xix Clarke, 117 . xx I also wonder about the notion of "freedom" as it applies to this novel. For the convict, prison is freedom; for Harry and Charlotte, their "escape" from bourgeois respectability becomes its own sort of prison, as they remain on the run from an engagement with society that they can never escape. xxi It is also striking that the mule and the Cajun man seem so interchangeable. While the mule is anthropomorphized by the convict, the "foreigners" in this novel -- both the "others" of the creole culture of Louisiana and the recent immigrants to Mississippi -- are rendered as inscrutable, with interiors as opaque as an animal's. The politics of "race" and ethnicity in this novel are, indeed, complex and fascinating; all kinds of distinctions and conflations emerge among African 
Americans, Cajuns, and more recent Chinese, Italian, and Scandinavian immigrants. xxii Minter, William Faulkner, 177. xxiii This faith in the land when "all else faltered" is particularly ironic given the massive instability of land itself in this section.

xxiv Janet Carey Eldred, "Faulkner's Still Life: Art and Abortion in The Wild Palms," in The Faulkner Journal: Faulkner and Feminisms V (fall 1988/spring 1989):149. [Yes, "Faulkner and Feminisms" is the issue title, not the journal title.] xxv Ibid., 149 . xxvi See Absalom, Absalom! for Faulkner's evocation of the tombstone as fading text.

xxvii I am grateful to Mitch Breitwieser for his insight into Harry"s vexed "return" to remembering. For the classic definitions of "mourning" and "melancholia," see Freud's distinction between the "normal" work of mourning, which entails a "letting go" of the lost love object and a return to life, and the pathological state of melancholia, which involves a static refusal to let go of an already lost love object. Sigmund Freud, "Mourning and Melancholia," in The Standard Edition of the Complete Psychological Works of 
Sigmund Freud, Vol. 1-24 (London: Hogarth Press and the Institute of Psycho-analysis, 1964): 14:237-258. 